\title{
Redescription of Quasiamidostomum fulicae (Rudolphi, 1819) Lomakin, 1991 (Nematoda: Amidostomatidae), a parasite of Fulica atra (Gruiformes)
}

\author{
Katarzyna Królaczyk ${ }^{1}$, Daniel Zaborski ${ }^{2}$, Emil Dzierzba ${ }^{3}$, Katarzyna M. Kavetska ${ }^{3}$ \\ ${ }^{1}$ Department of Animal Anatomy and Zoology, \\ ${ }^{2}$ Laboratory of Biostatistics, Faculty of Biotechnology and Animal Husbandry, \\ West Pomeranian University of Technology in Szczecin, 71-270 Szczecin \\ ${ }^{3}$ Laboratory of Biology and Ecology of Parasites, \\ Faculty of Biotechnology and Animal Husbandry, \\ West Pomeranian University of Technology in Szczecin, 71-466 Szczecin \\ katarzyna.krolaczyk@zut.edu.pl
}

Received: June 6, 2019 Accepted: February 12, 2020

\begin{abstract}
Introduction: Quasiamidostomum fulicae (Rudolphi, 1819) Lomakin, 1991, is a species of which the systematic position is still unclear, and it is reported in the literature under many synonyms. In the present study, an attempt has been made at establishing the ultimate systematic position of Quasiamidostomum fulicae against the backdrop of selected Amidostomatinae species. Material and Methods: The parasites were identified based on measurements of external and internal structures. Ecological analysis of $Q$. fulicae was carried out using the quantitative indices (frequency, prevalence, mean intensity, relative abundance, and dominance index). Statistical analyses (discriminant analysis) were performed on measurement data. Results: The intestines of 77 coots were examined. They yielded a total of 398 parasites, including 67 identified as $Q$. fulicae. Both males and females were located in the muscular gizzard. The morphometric analysis of $Q$. fulicae in this study showed the dimensions of all the internal organs to be in agreement with measurements reported by other authors. The discriminant analysis, used to find the differences between the examined nematode species (Amidostomoides acutum, A. petrovi, A. monodon, Amidostomum anseris, and Quasiamidostomum fulicae), gave highly significant results $(\mathrm{P}<0.0001)$ with respect to both males and females. Conclusion: The results justify the separation of $Q$. fulicae from the genus Amidostomum.
\end{abstract}

Keywords: coots, Quasiamidostomum fulicae, Amidostomatidae, Nematoda.

\section{Introduction}

Among nematodes parasitising the waterfowl, the most frequent are those representing the subfamily Amidostomatinae Travassos, 1919 (1, 2, 6, 7, 12, 13, $25,27)$. The subfamily at present comprise the following six genera: Amidostomum Railliet et Henry, 1909; Paramidostomum Freitas et Mendonca, 1949; Amidostomoides Petrova, 1987; Mesamidostomum Lomakin, 1991; Quasiamidostomum Lomakin, 1991; and Hexapapillostomum Lomakin, 1991 (3, 8, 18). Although the subfamily is thus divided according to the commonly adopted systematic classification, its structure is still debated by parasitologists. Most doubts are raised with respect to the genus Amidostomum identified by the presence of one or three teeth of almost equal length at the bottom of the buccal cavity and the spicules branching distally into two or three parts. The systematic assignment additionally relies on the ecology of those parasites with respect to their host specificity: they are almost exclusively restricted to birds of the order Anseriformes $(2,6)$.

The species of which the systematic positions are still unclear include Quasiamidostomum fulicae (Rudolphi, 1819) Lomakin, 1991, reported in the literature under as many as four synonyms: Spiroptera fulicae Rudolphi, 1819, Amidostomum raillieti Skrjabin, 1915, Amidostomum fulicae (Rudolphi, 1819) 
Seurat, 1918, and Amidostomum quasifulicae Macko, 1966. In addition, the species has been very frequently assigned to the genus Amidostomum and reported as $A$. fulicae (Rudolphi, 1819) $(1,9,25)$.

Quasiamidostomum fulicae occurs in the Eurasian coot Fulica atra, common moorhen Gallinula chloropus, and spotted crake Porzana porzana in the order Gruiformes, family Rallidae, and in the redcrested pochard Netta rufina in the order Anseriformes, family Anatidae, these all being definitive hosts. The nematode's distribution is across Great Britain, Spain, Italy, Bulgaria, Hungary, Poland, Ukraine, Lithuania, Latvia, and Russia.

An attempt was made at establishing the ultimate systematic position of Quasiamidostomum fulicae (Rudolphi, 1819) Lomakin, 1991 against the backdrop of selected Amidostomatinae species.

\section{Material and Methods}

The study is based on examination of 67 specimens of $Q$. fulicae. The nematodes were isolated from the gizzards of 77 Eurasian coots (Fulica atra) from north-western Poland. The coots were obtained from hunters during the autumn hunting seasons (15 August - 21 December) of 2007, 2009, and 2011.

The obtained results were compared with our previous results from examining 6,430 specimens of nematodes from the subfamily Amidostomatinae representing the three species Amidostomoides monodon, A. petrovi, and A. acutum (13). These nematodes were isolated from the gizzards of 1,005 waterfowl from north-western Poland obtained in 1999-2009. They had perished as a result of getting entangled in fishing nets while feeding.

The isolated nematodes were fixed in $70 \%$ ethanol and cleared in $80 \%$ lactic acid or in glycerine. The parasites were identified based on measurements of external structures (body length and width and vulvato-body-end distance) and internal organs (buccal cavity depth and wall thickness, lengths of teeth, muscular oesophagus, glandular oesophagus, spicules, gubernaculum, and ovijector, egg length and width, and tail length).

Ecological analysis of $Q$. fulicae was carried out using the following quantitative indices, selected with reference to Kisielewska (15, 16), Pojmańska (24), Bush et al. (4), and Kavetska (12): frequency of occurrence, incidence, intensity of occurrence, relative abundance, and dominance (WD, Janion's index). The values of the latter allowed $Q$. fulicae to be assigned to one of four groups differing in the degree of dominance in the host's nematofauna (12): superdominants (WD $\geq 10.0$ ), dominants $(10.0>\mathrm{WD} \geq 1.0)$, subdominants $(1.0>\mathrm{WD}$ $\geq 0.1$ ), or satellites (WD $<0.1$ ).

Statistical analyses were performed on measurement data of 211 mixed-species nematode specimens, incorporating those found to be best preserved. The analyses included 40 individuals of A. acutum (20 males and 20 females), 56 individuals of A. petrovi (28 males and 28 females), 48 individuals of A. monodon (23 males and 25 females), and 67 individuals of $Q$. fulicae (40 males and 27 females). To better elucidate interspecific differences, the discriminant analysis also included $A$. anseris (Zeder, 1800), the fifth species of the subfamily Amidostomatinae and a type species in the genus Amidostomum. As the authors had no specimens of $A$. anseris at their disposal, the morphometric data were sourced from the relevant publications $(6,19,27)$.

The discriminant analysis was performed to test for significance of differences between the nematode species examined (Amidostomoides acutum, A. petrovi, A. monodon, Amidostomum anseris, and Quasiamidostomum fulicae). Two sets of morphometric variables (one for males and another for females) were analysed. The male set comprised four variables (body length, buccal cavity depth, spicule length, and gubernaculum length) analysed across 117 cases (individuals). The female set involved three variables (body length, buccal cavity depth, and vulva-to-tail-end distance) analysed in 104 individuals. The contribution of each variable to discrimination between the nematode species studied was determined using the F statistic based on Wilks' lambda (5):

$$
\Lambda=\frac{|\mathbf{W}|}{|\mathbf{T}|}
$$

where $\Lambda$ is Wilks' lambda, $|\mathbf{W}|$ is the determinant of the within-group sums of squares and sums of crossproducts (SSCP) matrix, and $|\mathbf{T}|$ is the determinant of the total SSCP matrix.

In addition, variable redundancy was checked with the tolerance coefficient (26). The scatter of canonical values for the first two discriminant functions (Root 1 and Root 2) was plotted to visualise the separation between the five nematode species studied. The model assumptions (primarily normality of the multivariate distribution and homogeneity of between-groups variance) were tested. To check for the feasibility of morphometry-based classification of males and females, coefficients of classification functions were estimated; results were compiled in an error matrix (10). The calculations were performed with Statistica (v. 13 PL, Dell Inc., Round Rock, TX, USA) software and the mvnormtest package of $\mathrm{R}$ (11).

\section{Results}

Morphometric and ecological analysis of Quasiamidostomum fulicae (Rudolphi, 1819) Lomakin, 1991. The intestines of the 77 coots examined yielded a total of 398 parasites, 146 belonging to the phylum Nematoda. $Q$. fulicae was represented by 40 males and 27 females. Both males 
and females were curled S-like underneath the tough layer in the middle part of the gizzard.

The parasite was present in 14 out of the 77 coots examined (18.2\%) and occurred at a mean intensity of 4.8 (from 1 to 15 ). The relative abundance was 1.1. As indicated by the dominance index (12.18), Q. fulicae was a superdominant (WD $\geq 10.0$ ) in the coot nematode assemblage.

Q. fulicae had a filiform body covered with transversely striated cuticle. In both sexes, the anterior part of the body was characteristically tapered and devoid of any appendages (spines, setae, or bristles). The buccal cavity was very thick-walled and showed a large slim dorsal tooth, extending from the bottom of the buccal cavity almost to its edge (Fig. 1). Tables 1 and 2 contain the main morphological features and measurements as given by different authors.

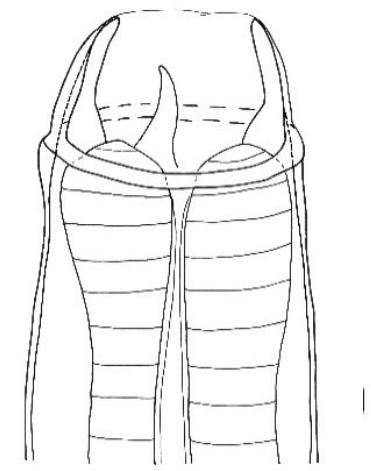

Fig. 1. Buccal capsule of Quasiamidostomum fulicae (Rudolphi, 1819) Lomakin 1991; scale bar: $10 \mu \mathrm{m}$

Males. The male body length ranged from 6.91 to $9.03 \mathrm{~mm}$ (mean of $7.9 \mathrm{~mm}$ ); the largest body width ranging from 130.0 to $200.0 \mu \mathrm{m}$ (mean of $156.0 \mu \mathrm{m}$ ) was found at the junction between the muscular and glandular oesophagus. The buccal cavity showed mean depth and wall thickness of 16.4 and $7.0 \mu \mathrm{m}$, respectively, and at its bottom was a single tooth measuring $13.6 \mu \mathrm{m}$ on average. The muscular (mean of $645.0 \mu \mathrm{m})$ to glandular $(130.0-210.0 \mu \mathrm{m}$; mean of

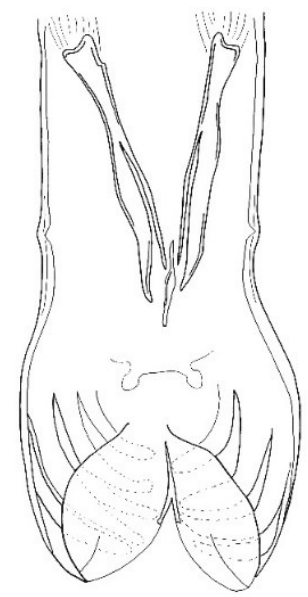

Fig. 2. Posterior region of the male Quasiamidostomum fulicae (Rudolphi, 1819) Lomakin 1991 body; scale bar: $50 \mu \mathrm{m}$
$128.0 \mu \mathrm{m})$ oesophagus length ratio was 5:1. The posterior part of the body (Fig. 2) presented a copulatory bursa with two laterally expanding cuticle lobes supported by one single and six paired hypodermal ribs. In most individuals examined, the lobes were bent towards the ventral surface of the body. The bursa ribs were arranged obliquely towards the posterior end, the terminal dorsal rib branching at the end into four arms. The males showed two spicules of almost equal length; the right spicule usually somewhat longer, but the length differences did not exceed $2.0 \mu \mathrm{m}$. A larger difference (up to $15.0 \mu \mathrm{m}$ ) was recorded in five individuals. The proximal parts of both spicules slightly broadened and at about mid-length branched off to form two arms, the internal one being clearly shorter. The spindle-shaped gubernaculum measuring $74.0 \mu \mathrm{m}$ on average was located between the copulatory setae. The gubernaculum was rounded distally and sharp-tipped proximally, and ventrally, its surface was slightly concave. The gubernaculum apex bore two oval post-cloacal glands set widely apart and directed outwards.

Females. The female body length varied extensively, from 5.24 to $13.46 \mathrm{~mm}$ (mean of $10.5 \mathrm{~mm}$ ), the body width being similar to that of males (mean of $160.0 \mu \mathrm{m}$ ). The muscular (mean of $712.0 \mu \mathrm{m}$ ) to glandular (120.0-200.0 $\mu \mathrm{m}$; mean of $129.0 \mu \mathrm{m})$ oesophagus length was 5.5:1. Compared to males, the females showed somewhat larger buccal cavities, with depth and width averaging 19.4 and $31.8 \mu \mathrm{m}$, respectively. The buccal cavity bottom supported a single tooth, slightly smaller than that in males $(11.3 \mu \mathrm{m}$ long). The vulva was situated at an average distance of $2.0 \mathrm{~mm}$ from the body end. The ovijector appeared large, with well-developed musculature, broadened in the mid-part and with length (including the muscles) found to range from 208.0 to $510.0 \mu \mathrm{m}$ (mean of $369.0 \mu \mathrm{m}$ ). The eggs were oval in shape, smooth, measuring $90.5 \times 59 \mu \mathrm{m}$ on average. The tail was long (mean length of $219.0 \mu \mathrm{m}$ ), straight, and tapered posteriorly (Fig. 3).

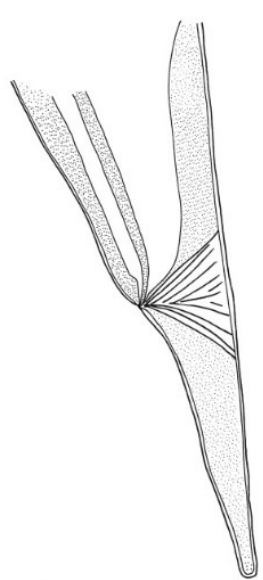

Fig. 3. Posterior region of the female Quasiamidostomum fulicae (Rudolphi, 1819) Lomakin 1991 body; scale bar: $50 \mu \mathrm{m}$ 
Table 1. Main morphological features and measurements of males of Quasiamidostomum fulicae (Rudolphi, 1819) Lomakin 1991, as given by different authors

\begin{tabular}{|c|c|c|c|c|c|c|}
\hline $\begin{array}{l}\text { Species and } \\
\text { Author }\end{array}$ & $\begin{array}{l}\text { A. fulicae /Rud./ } \\
\text { in Czapliński } \\
(6)\end{array}$ & $\begin{array}{l}\text { A. fulicae /Rud./ } \\
\text { in Pavlov (22) }\end{array}$ & $\begin{array}{l}\text { A. quasifulicae } \\
\text { in Macko (20) }\end{array}$ & $\begin{array}{l}\text { A. fulicae in } \\
\text { Petrova (23) }\end{array}$ & $\begin{array}{l}\text { Q. fulicae in } \\
\text { Lomakin (19) }\end{array}$ & $\begin{array}{l}\text { Q. fulicae } \\
\text { (present study) }\end{array}$ \\
\hline Host & $\begin{array}{l}\text { F. atra, } \\
\text { Aythya nyroca } \\
\text { Poland } \\
\text { (Mazovia) }\end{array}$ & $\begin{array}{l}\text { F. atra } \\
\text { Georgia }\end{array}$ & $\begin{array}{l}\text { Gallinula } \\
\text { chloropus }\end{array}$ & $\begin{array}{l}\text { F. atra } \\
\text { Bulgaria }\end{array}$ & $\begin{array}{l}F . \text { atra, } \\
\text { G. chloropus, } \\
P . \text { porzana, } \\
\text { A. fuligula }\end{array}$ & $\begin{array}{l}\text { F. atra } \\
\text { Poland } \\
\text { (West } \\
\text { Pomerania) }\end{array}$ \\
\hline $\begin{array}{l}\text { Body length } \\
(\mathrm{mm})\end{array}$ & $6.8-8.6$ & $5.8-8.8$ & $4.96-6.26$ & $6.54-8.61$ & $7.12-8.69$ & $6.91-9.03$ \\
\hline $\begin{array}{l}\text { Body width } \\
(\mu \mathrm{m})\end{array}$ & $160.0-192.0$ & $140.0-180.0$ & 136.0 & 132.0 & $170.0-210.0$ & $130.0-200.0$ \\
\hline $\begin{array}{l}\text { Buccal capsule } \\
\text { depth } \times \text { width } \\
(\mu \mathrm{m})\end{array}$ & $\begin{array}{l}12.6-15.6 \times \\
27.0-32.0\end{array}$ & width $21.0-27.0$ & $\begin{array}{l}12.0-14.0 \times \\
18.0-20.0\end{array}$ & 15.0 depth & $14.0 \times 22.0-26.0$ & $\begin{array}{l}14.9-22.5 \times \\
24.75-35.0\end{array}$ \\
\hline $\begin{array}{l}\text { Tooth } \\
\text { length }(\mu \mathrm{m})\end{array}$ & $10.8-13.0$ & - & $12.0-13.0$ & - & $9.0-12.0$ & $9.9-15.0$ \\
\hline $\begin{array}{l}\text { Muscular } \\
\text { oesophagus } \\
\text { length }(\mu \mathrm{m})\end{array}$ & $824.0-1073.0$ & $600.0-1100.0$ & $610.0-630.0$ & $829.0-993.0$ & - & 789.0-970.0 \\
\hline $\begin{array}{l}\text { Left spicule } \\
\text { length }(\mu \mathrm{m})\end{array}$ & $160.0-194.0$ & $1700-2100$ & & & & $153.0-212.0$ \\
\hline $\begin{array}{l}\text { Right spicule } \\
\text { length }(\mu \mathrm{m})\end{array}$ & $160.0-195.0$ & $1 / 0.0-210.0$ & $109.0-115.0$ & $155.0-199.0$ & $171.0-213.0$ & $153.0-232.0$ \\
\hline $\begin{array}{l}\text { Gubernaculum } \\
\text { length }(\mu \mathrm{m})\end{array}$ & $71.0-84.0$ & 46.0 & 53.0 & $68.0-81.0$ & $75.0-100.0$ & $59.0-104.0$ \\
\hline
\end{tabular}

Table 2. Main morphological features and measurements of females of Quasiamidostomum fulicae (Rudolphi, 1819) Lomakin 1991, as given by different authors

\begin{tabular}{|c|c|c|c|c|c|c|}
\hline Species and Author & $\begin{array}{l}\text { A. fulicae /Rud./ } \\
\text { in Czapliński } \\
(6)\end{array}$ & $\begin{array}{l}\text { A. fulicae /Rud./ } \\
\text { in Pavlov (22) }\end{array}$ & $\begin{array}{l}\text { A. quasifulicae } \\
\text { in Macko (28) }\end{array}$ & $\begin{array}{l}\text { A. fulicae } \\
\text { in Petrova (23) }\end{array}$ & $\begin{array}{l}\text { Q. fulicae } \\
\text { in Lomakin (19) }\end{array}$ & $\begin{array}{l}\text { Q. fulicae } \\
\text { (present study) }\end{array}$ \\
\hline Host & $\begin{array}{l}\text { F. atra, } \\
\text { Aythya nyroca } \\
\text { Poland } \\
\text { (Mazovia) }\end{array}$ & $\begin{array}{l}F . \text { atra } \\
\text { Georgia }\end{array}$ & $\begin{array}{l}\text { Gallinula } \\
\text { chloropus }\end{array}$ & $\begin{array}{l}\text { F. atra } \\
\text { Bulgaria }\end{array}$ & $\begin{array}{l}F . \text { atra, } \\
\text { G. chloropus, } \\
P . \text { porzana, } \\
\text { A. fuligula }\end{array}$ & $\begin{array}{l}\text { F. atra } \\
\text { Poland (West } \\
\text { Pomerania) }\end{array}$ \\
\hline Body length (mm) & $6.5-12.3$ & $8.2-12.4$ & 8.1 & $6.64-11.52$ & $8.4-12.74$ & $5.24-13.46$ \\
\hline Body width $(\mu \mathrm{m})$ & $160.0-232.0$ & 275.0 & 142.0 & 174.0 & $200.0-240.0$ & $120.0-210.0$ \\
\hline $\begin{array}{l}\text { Buccal capsule } \\
\text { depth } \times \text { width }(\mu \mathrm{m})\end{array}$ & $\begin{array}{l}15.0-17.3 \times \\
30.0-33.0 \\
\end{array}$ & width $20.0-26.0$ & $16.0 \times 20.0$ & - & $\begin{array}{l}11.0-18.0 \times \\
24.0-27.0 \\
\end{array}$ & $\begin{array}{l}15.0-24.8 \times \\
24.75-35.0 \\
\end{array}$ \\
\hline $\begin{array}{l}\text { Tooth } \\
\text { length }(\mu \mathrm{m})\end{array}$ & $13.4-15.5$ & - & 14.0 & - & $11.0-14.0$ & $9.9-14.9$ \\
\hline $\begin{array}{l}\text { Muscular } \\
\text { oesophagus length } \\
(\mu \mathrm{m})\end{array}$ & $580.0-1100.0$ & $800.0-1100.0$ & 651.0 & $931.0-1281.0$ & - & $660.0-1000.0$ \\
\hline $\begin{array}{l}\text { Vulva distance from } \\
\text { posterior end (mm) }\end{array}$ & $1.3-2.18$ & $1.8-2.5$ & 1.95 & $1.74-2.05$ & - & $1.78-2.43$ \\
\hline $\begin{array}{l}\text { Egg length } \times \text { width } \\
(\mu \mathrm{m})\end{array}$ & $\begin{array}{l}89.0-96.0 \times \\
62.0-66.0 \\
\end{array}$ & $\begin{array}{l}102.0-111.0 \times \\
55.0-69.0\end{array}$ & $\begin{array}{l}81.0 \times 52.0- \\
66.0\end{array}$ & $\begin{array}{l}99.0-105.0 \times \\
62.0-74.0\end{array}$ & $\begin{array}{l}94.0-113.0 \times \\
61.0-73.0\end{array}$ & $\begin{array}{l}85.0-109.0 \times \\
49.5-74.0\end{array}$ \\
\hline Tail length $(\mu \mathrm{m})$ & $129.0-225.0$ & - & 154.0 & $186.0-208.0$ & $180.0-240.0$ & $114.0-272.0$ \\
\hline
\end{tabular}

Q. fulicae vs. nematodes of the genera Amidostomum and Amidostomoides. The present authors' research revealed substantial morphological differences between the five nematode species studied (Table 3). Q. fulicae was found to differ from $A$. anseris, a type species in the genus Amidostomum, in having a single tooth in the buccal cavity. Both (right and left) spicules in male A. anseris are equal in length and almost twice as long $(268.0-415.0 \mu \mathrm{m})$ as those in males of $Q$. fulicae, of which the right spicule (mean length of $193.7 \mu \mathrm{m}$ ) is somewhat longer than the left one (mean length of $192.4 \mu \mathrm{m}$ ). The $Q$. fulicae spicules differ in shape from those in the genus Amidostomum. The spicules of Q. fulicae are slightly broadened proximally and branch off in the mid-part, whereas the Amidostomum spicules broaden distally into two or three parts.
The presence of a single tooth on the bottom of the buccal cavity is a feature common to $Q$. fulicae and the three species Amidostomoides acutum, A. petrovi, and A. monodon, which, until recently, were reported as a single species complex Amidostomum acutum. Both spicules and the muscular oesophagus in Amidostomoides are shorter than those in $Q$. fulicae (Table 3). Unique characteristics of the genus Amidostomoides include the transversely striated (grooved) cuticle and typical processes (warts) surrounding the buccal cavity.

Differences between the species studied were assessed using discriminant analysis. The method has already been successfully applied in studies aimed at identifying species comprising the species complex Amidostomum acutum $(13,14)$. 
The assumption of the morphometric variable multivariate distribution normality was not fulfilled, as the group variances of all the morphometric variables analysed showed statistically significant differences. However, as pointed out by Klecka (17), the best measure of a model's applicability is the percentage of correct classifications, which was relatively high in this study (Table 4).

The discriminant analysis yielded highly significant results with respect to both males and females $(\Lambda=0.0066, F=87.1560, P<0.0001$ for males and $\Lambda=0.0853, \mathrm{~F}=32.8660, \mathrm{P}<0.0001$ for females). As shown in Table 5, three morphometric variables in males (body length, buccal cavity depth, and spicule length) significantly contributed to discrimination between the species. In females, all the variables analysed were significant in discriminating between the five species. In both sexes, the morphometric variables showed relatively high tolerance coefficients, evidencing lack of variable redundancy.

To visualise differences between the species studied, scatter diagrams of canonical values for the first two discriminant functions were plotted for males and females (Figs 4 and 5). In males, the first discriminant function (Root 1, Fig. 4) is seen to clearly discriminate between $A$. anseris together with Q. fulicae from the three remaining species. The data points representing individuals of the two species are located in the left-hand part of the diagram and form separate groups. In females, the first discriminant function fairly distinctly separated $Q$. fulicae from the remaining four species (data points in the right-hand side of the plot), the second discriminant function separating mainly $A$. anseris from the remaining three species (data points in the lower part of the diagram).

Table 3. Comparison of main morphological features and measurements of nematodes (A. acutum, Q. fulicae, and A. anseris)

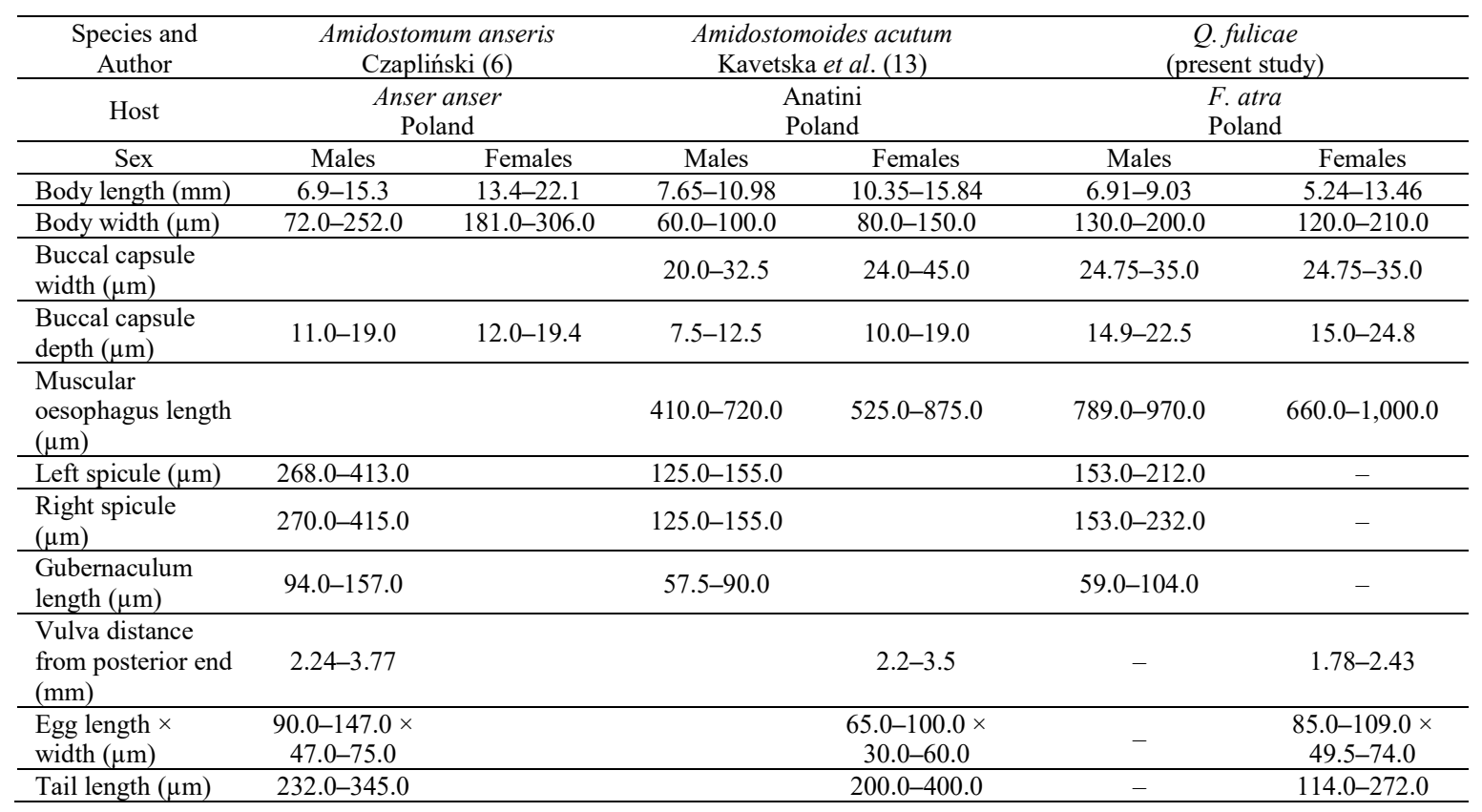

Table 4. Results of the error matrix for five nematode species

\begin{tabular}{|c|c|c|c|c|c|c|}
\hline \multirow{2}{*}{ Species } & \multirow[t]{2}{*}{ Correct percentage } & \multicolumn{5}{|c|}{ Predicted species } \\
\hline & & A. acutum & A. petrovi & A. monodon & Q. fulicae & A. anseris \\
\hline \multicolumn{7}{|c|}{ Males } \\
\hline A. acutum & 95.00 & $19^{\mathrm{a}}$ & 1 & 0 & 0 & 0 \\
\hline A. petrovi & 92.86 & 2 & 26 & 0 & 0 & 0 \\
\hline A. monodon & 86.96 & 1 & 2 & 20 & 0 & 0 \\
\hline Q. fulicae & 100.00 & 0 & 0 & 0 & 40 & 0 \\
\hline A. anseris & 100.00 & 0 & 0 & 0 & 0 & 6 \\
\hline Total & 94.87 & 22 & 29 & 20 & 40 & 6 \\
\hline \multicolumn{7}{|c|}{ Females } \\
\hline A. acutum & 55.00 & 11 & 7 & 2 & 0 & 0 \\
\hline A. petrovi & 85.71 & 3 & 24 & 1 & 0 & 0 \\
\hline A. monodon & 80.00 & 5 & 0 & 20 & 0 & 0 \\
\hline Q. fulicae & 96.30 & 0 & 1 & 0 & 26 & 0 \\
\hline A. anseris & 50.00 & 0 & 2 & 0 & 0 & 2 \\
\hline Total & 79.81 & 19 & 34 & 23 & 26 & 2 \\
\hline
\end{tabular}

${ }^{a}$ bold entries are numbers of correctly classified cases 
Table 5. Results of the discriminant analysis for males and females (A. acutum, A. petrovi, A. monodon, Q. fulicae, and A. anseris)

\begin{tabular}{|c|c|c|c|c|}
\hline Variable & Lambda & $\mathrm{F}$ & Tolerance & $\mathrm{P}^{\mathrm{a}}$ \\
\hline \multicolumn{5}{|l|}{ Males } \\
\hline Body length & 0.0426 & 149.5096 & 0.4392 & 0.0000 \\
\hline Buccal capsule depth & 0.0129 & 26.2035 & 0.843 & 0.0000 \\
\hline Spicule length & 0.0383 & 131.387 & 0.4298 & 0.0000 \\
\hline Gubernaculum length & 0.0067 & 0.6823 & 0.734 & 0.6057 \\
\hline \multicolumn{5}{|l|}{ Females } \\
\hline Body length & 0.1328 & 13.4937 & 0.3673 & 0.0000 \\
\hline Buccal capsule depth & 0.1514 & 18.7772 & 0.848 & 0.0000 \\
\hline Vulva distance from posterior end & 0.1713 & 24.42 & 0.385 & 0.0000 \\
\hline
\end{tabular}

${ }^{\text {a }}$ Bold entries are statistically significant results $(\mathrm{P} \leq 0.05)$

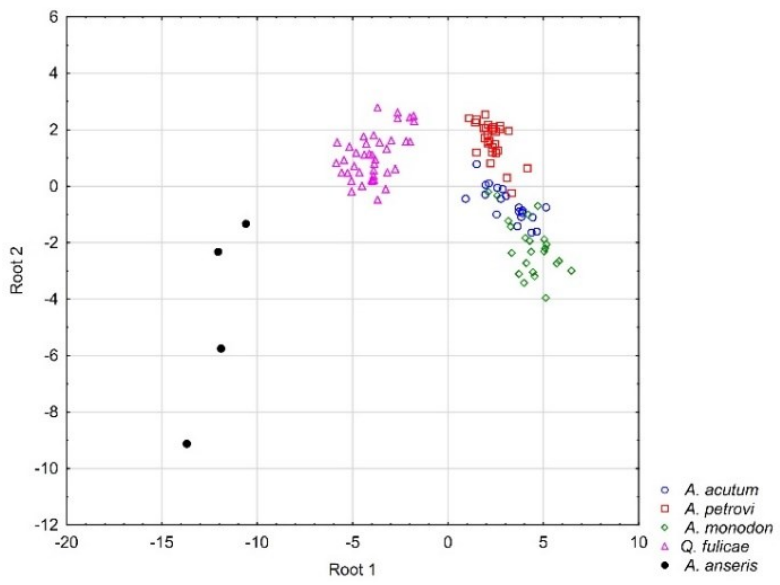

Fig. 4. Scatter plot of canonical values for males of the species analysed

As shown in Table 4, results of the discriminant function-based classification evidence a substantial discriminant power of the morphometric characteristics selected for the analysis (body length, buccal cavity depth, spicule length, and gubernaculum length in males as well as body length, buccal cavity depth, and vulva-tail-end distance in females) and their suitability for differentiating between the five nematode species studied. It should be borne in mind, however, that the classification is only a post-hoc one.

\section{Discussion}

The first report on a nematode which is presumably $Q$. fulicae dates back to 1819 when Rudolphi isolated a nematode which he named Spiroptera fulicae (Rudolphi, 1819) from the stomach of the Eurasian coot (Fulica atra). Rudolphi, however, provided no morphological description of the nematode (19). Almost a hundred years later, Seurat transferred Spiroptera fulicae to the genus Amidostomum, thus changing the name to Amidostomum fulicae (Seurat, 1918). Independently of Seurat, Skrjabin provided another description of a species, namely $A$. raillieti (Skrjabin, 1915). He found a male in a coot's appendix and based his differentiation on three fine teeth and a different location in the host. A breakthrough came

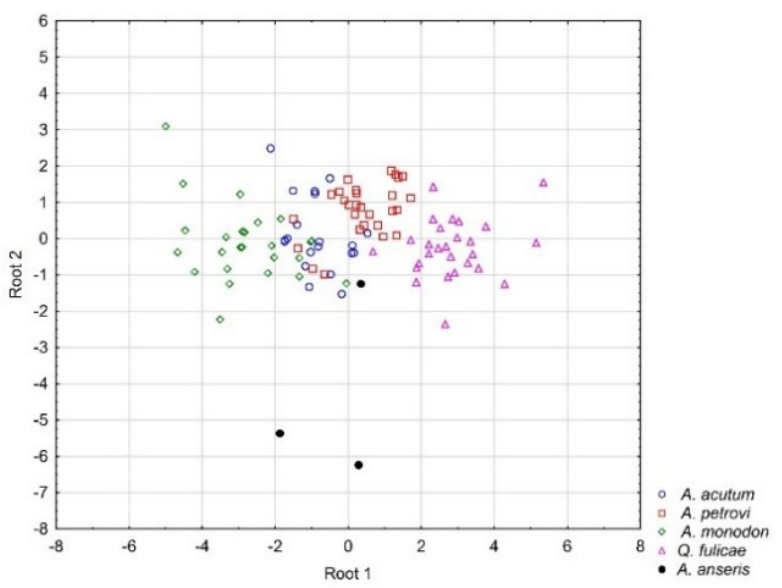

Fig. 5. Scatter plot of canonical values for females of the species analysed

with the studies of Pavlov (22), who was the first to provide a full morphological description of both species ( $A$. fulicae and $A$. raillieti) and decided that $A$. raillieti was a synonym of $A$. fulicae.

Soon afterwards, another description of an Amidostomum species was published and the nematode identified as A. quasifulicae (Macko, 1966). It was isolated from the gizzard of the common moorhen Gallinula chloropus in the order Gruiformes (20). The parasite was described based on measurements of four males and a single female. According to Macko (20), the basic differences between $A$. fulicae and A. quasifulicae stem from differing dimensions of spicules and the gubernaculum: $0.160-0.210$ and $0.060-0.108 \mu \mathrm{m}$, respectively, in $A$. fulicae and $0.109-0.115$ and $0.046 \mu \mathrm{m}$, respectively, in A. quasifulicae. Moreover, that author observed differences in other organs (e.g. the oesophagus or oviduct) and eggs. Regardless of morphological differences, Macko emphasised the phylogenetic affinity between the two species, manifested as settlement in the stomachs of closely related hosts.

Important for bringing some order to information on the Amidostomum nematodes was the research of Petrova (23). Based on differences in morphology and host specificity, she divided the genus Amidostomum into two subgenera. In her opinion, the Amidostomum subgenus groups nematodes with three teeth in the deep 
buccal cavity (Amidostomum anseris, A. spatulatum, and A. cygni), while the Amidostomoides subgenus groups nematodes with a single tooth in a shallow buccal cavity (A. acutum, A. quasifulicae, and A. fulicae).

In his revision, Lomakin $(18,19)$ resolved both the taxonomic affiliation and nomenclature of the nematode. He raised Petrova's subgenus Amidostomoides to the species level. Moreover, in addition to the hitherto extant genera Paramidostomum Freitas and Mendonca, 1949 and Amidostomum Railliet and Henry, 1909, he distinguished three new ones: Hexapapillostomum, Mesamidostomum, and Quasiamidostomum.

Lomakin $(18,19)$ focused primarily on the Amidostomum nematodes. He found the description of A. quasifulicae provided by Macko (20) had been based on a low number of young individuals and supported this statement by calculating an " $x$ " index (6) which amounted to $35.4-49.6$ in his research on A. fulica, the range of 45.5-54.4 being assigned to A. quasifulicae based on data provided by Macko (20). In Lomakin's opinion, the morphological characteristics provided by Macko (20), namely the structure of the oesophagus, arrangement of the bursa wings and the spicule structure are indicative of a close affinity between A. fulicae and $A$. quasifulicae. Therefore, Lomakin decided to regard $A$. fulicae and $A$. quasifulicae as synonyms, and he transferred $A$. quasifulicae to a new genus which he erected. That genus was Quasiamidostomum, and A. quasifulicae was ascribed to the genus as $Q$. fulicae $(18,19)$.

The morphometric analysis of $Q$. fulicae in this study showed the dimensions of all the internal organs to be in agreement with measurements reported by Czapliński (6), Pavlov (22), Macko (20), Petrova (23), and Lomakin (19). Not only does the agreement confirm the identity of the individuals examined as representatives of $Q$. fulicae, but allows the conclusion that the years-long discussion among parasitologists concerned the same nematode species the whole time.

The discriminant analysis eventually confirmed that three morphometric variables of males (body length, buccal cavity depth, and spicule length) as well as all the morphometric variables of females significantly contributed to discrimination among the Amidostomatinae species analysed. The scatterplots of canonical values for the discriminant functions showed $Q$. fulicae to be clearly different from other species.

The results of many years of the authors' own research confirm host specificity to be important in nematode classification. Such a close relationship has been reported by Kavetska $(12,13)$ who showed Amidostomoides acutum to be found exclusively in the true ducks (Anatini), A. petrovi to parasitise the Aythyini ducks and the common goldeneye (Mergini), and $A$. monodon to occur in sea ducks (Mergini). The available literature unequivocally classifies $A$. anseris as a parasite of geese, and only sporadically as a parasite of the Anatinae ducks $(6,19,21)$. A close host specificity was observed in $Q$. fulicae. The parasite was almost exclusively reported from the coot $(6,19$, $22,23,28)$ and was much rarer in the other Gruiformes Gallinula chloropus (20) and Porzana porzana (19) as well as in the Anseriformes Aythya fuligula (19) and A. nyroca (6).

The results of statistical, morphological, and ecological analyses justify the separation of $Q$. fulicae from the genus Amidostomum.

Conflict of Interests Statement: The authors declare that there is no conflict of interests regarding the publication of this article.

Financial Disclosure Statement: This work was supported by the Polish Ministry of Science and Higher Education, grant no. 517-01-047-4550/17.

Animal Rights Statement: All experiments on animals were conducted in accordance with local Ethical Committee laws and regulations as regards care and use of laboratory animals.

\section{References}

1. Anderson R.C.: Nematode parasites of vertebrates: their development and transmission. CABI Publishing, Wallingford, 2000, pp. 84-87.

2. Baruš V., Sergeeva T.P., Sonin M.D., Ryzhikov K.M.: Helminth of fish-eating birds of the palaearctic region I Nematoda. Academia Praha, Prague, 1978, pp. 50-52.

3. Beveridge J., Spratt D.M., Durette-Desset M.C: Order Strongylida (Raillett \& Henry, 1913). In: Handbook of zoology. Gastrotricha, cycloneuralia and gnathifera. Vol. 2: Nematoda, edited by A. Schmidt-Rhaesa, De Gruyter, Berlin, 2013.

4. Bush A.O., Lafferty K.D., Lotz J.M., Shostaki A.W.: Parasitology meets ecology on its own terms. J Parasitol 1997, $83,575-583$.

5. Carlberg C.: Decision analytics: Microsoft Excel. Que Publishing, Indianapolis, 2013.

6. Czapliński B.: Nematodes and Acanthocephalans of domestic and wild Anseriformes in Poland, I. Revision of the genus Amidostomum. Acta Parasitol Pol 1962, 10, 154-159.

7. Fedynich A.M., Thomas N.J.: Amidostomum and Epomidiostomum. In: Parasitic diseases of wild birds edited by C.T. Atkinson, N.J. Thomas, D.B. Hunter, Wiley-Blackwell, London, 2008, pp. 355-375.

8. Gibbons L.M.: Keys to the nematode parasites of vertebrate. Supplementary volume. CABI Publishing, Wallingford, 2010, pp. 98-102.

9. Gibson D.: Fauna Europaea: Amidostomum. https://fauna-eu.org.

10. Hill T., Lewicki P.: Statistics: methods and applications. StatSoft Inc, Tulsa OK, 2006.

11. Jarek S.: Mvnormtest: normality test for multivariate variables. $\mathrm{R}$ package version 0.1-9. http://CRAN.R-project.org/package $=$ mvnormtest.

12. Kavetska K.M.: Biological and ecological conditions of the formation of the nematode fauna of wild ducks in north west Poland. Habilitation dissertation No 235. Agricultural Academy, Szczecin, 2006.

13. Kavetska K.M., Królaczyk K., Stapf A., Grzesiak W., Kalisińska E., Pilarczyk B.: Revision of the species complex Amidostomum acutum (Lundahl, 1848) (Nematoda: Amidostomatidae). Parasitol Res 2011, 109, 105-117. 
14. Kavetska K.M., Polasik D., Dzierzba E., Jędrzejczak M., Kalisińska E., Rząd I.: Revision of the species complex Amidostomum acutum (Lundahl, 1848) (Nematoda: Amidostomatidae) by use of molecular techniques. Ann Parasitol 2015, 61, 43-48.

15. Kisielewska K.: Natural groupings of parasites as a subject of parasitological research. Kosmos 1968, 14, 51-61.

16. Kisielewska K.: Ecological organization of intestinal helminth groupings in Clethrionomys glareolus (Schreb.) (Rodentia). I. Structure and seasonal dynamics of helminth groupings in a host population in the Białowieża Park. Acta Parasitol Pol 1970, 18, 121-147.

17. Klecka W.R.: Discriminant Analysis. SAGE, London, 1970.

18. Lomakin V.V.: Revision of the family Amidostomatidae (Nematoda, Strongylida). Gelminol Zhivotnych 1991, 38, 70-85.

19. Lomakin V.V.: Revision of nematodes of the subfamily Amidostomatinae Travossos, 1919 (Amidostomatidae; Strongylida). Trudy Gelmintol Lab 1993, 39, 92-122.

20. Macko J.K.: Amidostomum quasifulicae sp. nov. (Nematoda: Strongylata) von Gallinula chloropus L. Annot Zool Bot 1966, 28, 9-12.

21. Okulewicz A.: The catalogue of parasitic fauna of Poland. Part IV. Parasites of birds. 2B - Nematoda). Polish Parasitol Soc, Warsaw, 1997, pp. 75-76.
22. Pavlov A.V.: Identification of species Amidostomum fulicae (Rud., 1819) and Amidostomum raillieti Skrjabin 1915). Trudy Gelmintol Lab 1960, 10, 166-172.

23. Petrova K.: Species composition and morphology of Nematodes from the genus Amidostomum Railliet et Henry, 1909 (Strongylata: Amidostomatidae) in Bulgaria. Khelmintologiya 1987, 24, 53-72.

24. Pojmańska T.: Review of ecological terms used today in parasitology. Ann Parasitol 1993, 39, 285-297.

25. Pojmańska T., Niewiadomska K., Okulewicz A.: Parasitological helminths of Poland. Species, hosts, white spots. Polish Parasitol Soc, Warsaw, 2007: p. 139

26. Rovai A.P., Baker J.D., Ponton M.K.: Social science research design and statistics: A practitioner's guide to research methods and IBM SPSS. Watertree Press LLC, Chesapeake, 2013, p. 628.

27. Ryšavỳ B., Groschaft J., Baruš V., Dvořaková L.: Helminths of water birds. Československé akademie vĕd, Prague, 1982, pp. 177-179.

28. Seurat L.G.: Sur un nouveau strongle (Trichostrongylidae) de l'échasse (On a novel strongylid (Trichostrongylidae) found in the stilt - in French). Bull Muséum Natl d'Histoire Natur 1918, $24,113-115$. 